\title{
Ouabain inhibits p38 activation in mice neutrophils
}

\author{
Luiz Henrique Agra Cavalcante-Silva ${ }^{1}$ (1) . Deyse Cristina Madruga Carvalho ${ }^{1}$. Éssia de Almeida Lima ${ }^{1}$. \\ Sandra Rodrigues-Mascarenhas ${ }^{1}$ (I)
}

Received: 11 August 2021 / Accepted: 10 October 2021 / Published online: 18 November 2021

(c) The Author(s), under exclusive licence to Springer Nature Switzerland AG 2021

\begin{abstract}
Ouabain is a cardiac steroid hormone with immunomodulatory effects. It inhibits neutrophils migration induced by different stimuli, but little is known about the mechanisms involved in this effect. Thus, the aim of this study was to evaluate the ouabain effect on chemotactic signaling pathways in neutrophils. For that, mice neutrophils were isolated from bone marrow, treated with ouabain $(1,10$, and $100 \mathrm{nM})$ for $2 \mathrm{~h}$, submitted to transwell chemotaxis assay and flow cytometry analysis of Akt, ERK, JNK, and p38 phosphorylation induced by zymosan. Ouabain treatment $(1,10$ and, $100 \mathrm{nM})$ reduces neutrophil chemotaxis induced by chemotactic peptide fMLP, but this substance did not inhibit Akt, ERK, and JNK activation induced by zymosan. However, ouabain $(1$ and $10 \mathrm{nM})$ reduced p38 phosphorylation in zymosan-stimulated neutrophils. These results suggest that ouabain may interfere in neutrophil migration through p38 MAPK inhibition.
\end{abstract}

Keywords Cardiac steroid $\cdot$ Akt $\cdot$ MAPK $\cdot$ Neutrophil migration

\section{Introduction}

Ouabain is a cardiac steroid hormone produced mainly by the adrenal gland, that modulates many immune system functions (Rodrigues-Mascarenhas et al. 2009), including the inflammatory response (Cavalcante-Silva et al. 2017). Our group has previously demonstrated that ouabain inhibits mice neutrophil migration induced by zymosan (Leite et al. 2015), ovalbumin (Galvão et al. 2017), Leishmania amazonensis (Jacob et al. 2013), and concanavalin A (de Vasconcelos et al. 2011). Other studies have also reported this activity in human neutrophils (Ray and Samanta 1997). The impairment of neutrophil migration by ouabain could be related to reduced CD18 expression, an integrin beta- 2 chain (Cavalcante-Silva et al. 2020). Cardiotonic steroids inhibit $\mathrm{Na}^{+} / \mathrm{K}^{+}$-ATPase (NKA) and alter cellular ion concentration. However, ouabain-NKA interaction, without pump inhibition, can also interfere with cellular signaling (e.g., MAPK pathway) (Cui and Xie 2017), modulating different cellular

Sandra Rodrigues-Mascarenhas

sandra@cbiotec.ufpb.br

1 Immunobiotechnology Laboratory, Biotechnology Center, Federal University of Paraíba, João Pessoa 58051-900,

Brazil functions, such as cell proliferation (Aydemir-Koksoy et al. 2001).

Neutrophils are polymorphonuclear leukocytes classically known to participate in inflammatory processes and play an important role in bacterial and fungal infections (Summers et al. 2010). However, neutrophils also participate in the tumor immune response (Mishalian et al. 2017; Ocana et al. 2017), the stimulation of adaptive immune responses (Minns et al. 2019), and also the resolution of inflammation (Jones et al. 2016) and healing (Phillipson and Kubes 2019). Despite their essential role in immune system homeostasis, neutrophils are also involved in the immunopathology of many inflammatory diseases, such as acute lung injury, chronic obstructive pulmonary disease, arthritis, and COVID-19 (Leliefeld et al. 2016; Juss et al. 2016; Hellebrekers et al. 2018; Bautista-Becerril et al. 2021; Cavalcante-Silva et al. 2021; Parackova et al. 2021). These cells present a dysregulated migration or activation in these clinical conditions (Hidalgo et al. 2019).

Considering that ouabain can reduce neutrophil migration (Leite et al. 2015), but little is known about the molecular mechanisms involved in this effect, this work aimed to evaluate the ouabain effect on cell signaling pathways related to neutrophil migration. 


\section{Materials and methods}

\section{Animals}

In this work, female Swiss albino mice (6-7 weeks) were acquired from the Federal University of Paraíba (UFPB, João Pessoa, Brazil). The mice were kept under standard laboratory conditions on a constant 12-h light/dark, food and water ad libitum, with cycle with controlled temperature $\left(21 \pm 1{ }^{\circ} \mathrm{C}\right)$. All procedures adopted in this study were approved by the Institutional Ethics Committee (protocol: 039/2015, date of approval of the animal study was 10/05/2017).

\section{Reagents}

Ouabain was obtained from Sigma-Aldrich (O3125). The following antibodies were used: anti-CD16/CD32 (eBioscience), anti-Gr-1 (eBioscience), anti-TLR2 (eBioscience), anti-P-ERK1/2 (pT202/pY204) (BD Biosciences), anti-Pp38 (pT180/pY182) (BD Biosciences), anti-P-Src (Y418) eBioscience, anti-Akt (pS473) (eBioscience). Transwell plates (CLS3421-48EA) were obtained from Sigma-Aldrich.

\section{Transwell protocol}

Neutrophils were isolated as previously described (Mocsai et al. 2003; Cavalcante-Silva et al. 2020). Neutrophil chemotaxis was assessed using a transwell system. The cell suspension $\left(1.0 \times 10^{6}\right.$ neutrophils/well) ouabain-treated (1, 10 , and $100 \mathrm{nM}$ ) was placed in the upper compartment of the chamber, while a chemotaxis stimulus (fMLP, $100 \mathrm{nM}$ ) was placed in the lower compartment. These compartments were separated by polycarbonate membrane ( $5 \mu \mathrm{m}$ pore size) and the chamber was incubated at $37{ }^{\circ} \mathrm{C}$ for $2 \mathrm{~h}$. At the end of the incubation period, cell migration was determined by counting cell numbers in the lower compartment using a hemocytometer chamber. The migration index for each sample was calculated by the ratio of the cell number in the upper compartment in wells with fMLP and the cell number in medium-only wells (random spontaneous cell migration) (Lima et al. 2014).

\section{Flow cytometry protocols}

The neutrophils isolated from bone marrow were treated in vitro with ouabain $(1,10$, and $100 \mathrm{nM})$ for $2 \mathrm{~h}$ and stimulated or not with zymosan $(100 \mu \mathrm{g} / \mathrm{mL})$. In summary, the neutrophils were pre-incubated with anti-mouse CD16/ CD32 to block non-specific Fc-mediated interactions. Later, the cells were stained with anti-Gr-1 and anti-TLR2 antibodies for $30 \mathrm{~min}$ at $4{ }^{\circ} \mathrm{C}$. To intracellular staining, cells were fixed and permeabilized, then stained with anti-p-p38, p-ERK, p-JNK, p-Akt. The cells were then washed with cold PBS and resuspended in the same solution for flow cytometry analysis (10,000 events were acquired). The experiments were performed at least twice.

\section{Statistical analysis}

All data are expressed as the mean \pm SD and were analyzed by GraphPad Prism 8.0 software using one-way analysis of variance (ANOVA) followed by Dunnett's test. The results were considered statistically significant when $p<0.05$. The flow cytometry data were analyzed using FlowJo 10 software.

\section{Results}

Transwell assay demonstrated that fMLP peptide stimulation was able to induce neutrophil migration. Furthermore, ouabain treatment reduced fMLP-induced migration by $80.12 \%$ (1 nM), 76.24\% (10 nM) and 56.36\% (100 nM) (Fig. 1a). In contrast, ouabain treatment $(1,10$, and $100 \mathrm{nM})$ did not modulate Akt activation induced by zymosan (Fig. 1b). Next, we assessed the effect of ouabain on MAPK signaling activation induced by zymosan. Ouabain did not interfere with ERK and JNK phosphory-lation (Fig. 1c, d). However, ouabain reduced p38 phosphorylation level by $39.41 \%(1 \mathrm{nM})$ and $60.64 \%$ (10 nM) (Fig. 1e). It is noteworthy that ouabain $(1,10$, and $100 \mathrm{nM})$ did not change the basal phosphorylation levels of assessed targets (Fig. 1.b-e) in the absence of zymosan and this effect is independent of reduced zymosan receptor (TLR2) expression (Fig. 1f).

\section{Discussion}

The neutrophil is one of the cells recruited to tissues during an inflammatory response. The classic cell recruitment generally follows a stepwise model, including tethering, rolling, adhesion, crawling, and transmigration step (Kolaczkowska and Kubes 2013; Liew and Kubes 2019). A previous study showed that ouabain could interfere with the adhesion step since it reduces CD18 adhesion molecule expression (Cavalcante-Silva et al. 2020). In the transwell model, cells added in the upper compartment can migrate through a porous membrane to the lower chamber due to a chemotactic gradient. This approach resembles the transmigration of cells from blood vessels to extravascular tissue. In this assay, fMLP peptide stimulation was able to induce neutrophil migration. Furthermore, ouabain treatment reduced fMLP-induced transmigration/chemotaxis. This result is in 
Fig. 1 Ouabain effect on mice neutrophil. a Ouabain reduces neutrophil transmigration towards fMLP gradient $(100 \mathrm{nM})$. b Ouabain effect on Akt kinase. c-e Ouabain effect on MAPK proteins. f Ouabain effect on TLR2. $* p<0.05$ vs control; $\# p<0.05$ vs fMLP or zymosan. b-e Frequencies of phosphorylated proteins in neutrophil normalized by control and expressed as mean $\pm \mathrm{SD}$

(a.u., arbitrary unit), $(n=4-5)$
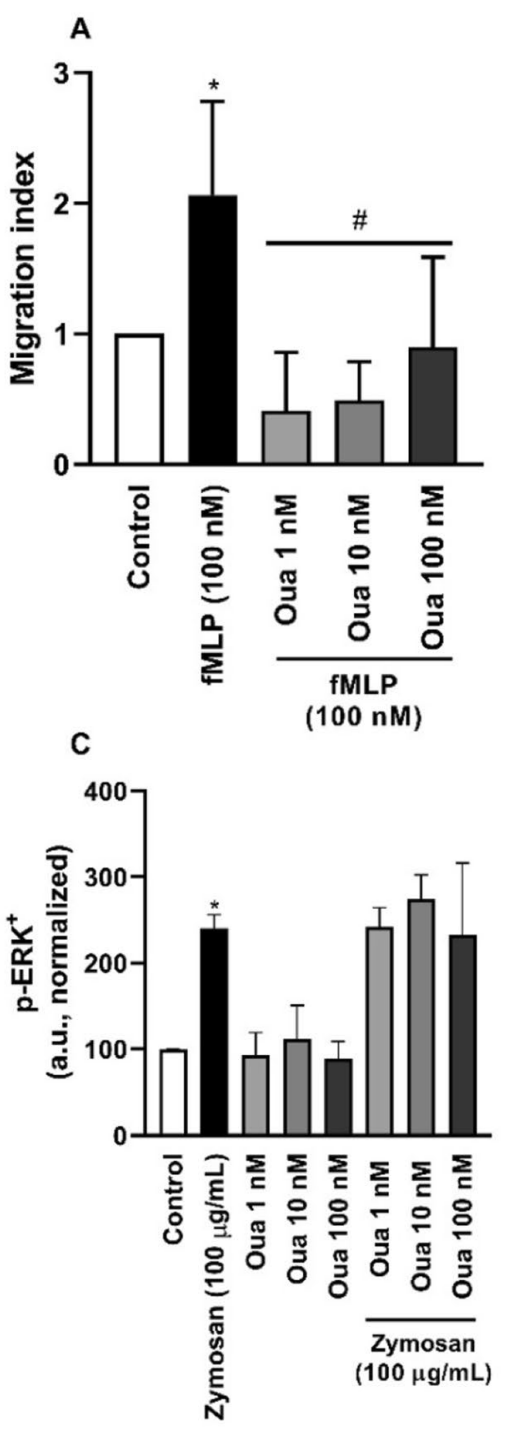

E

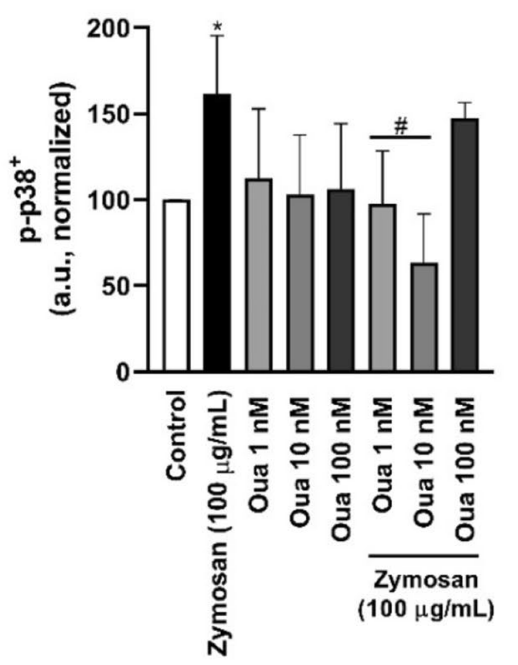

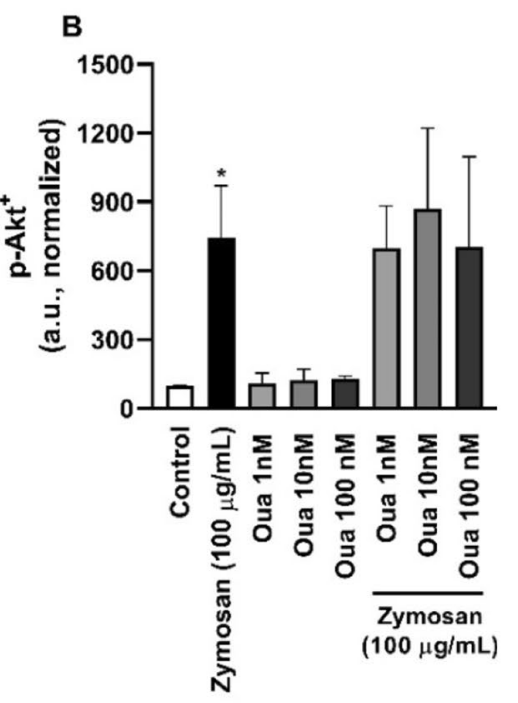
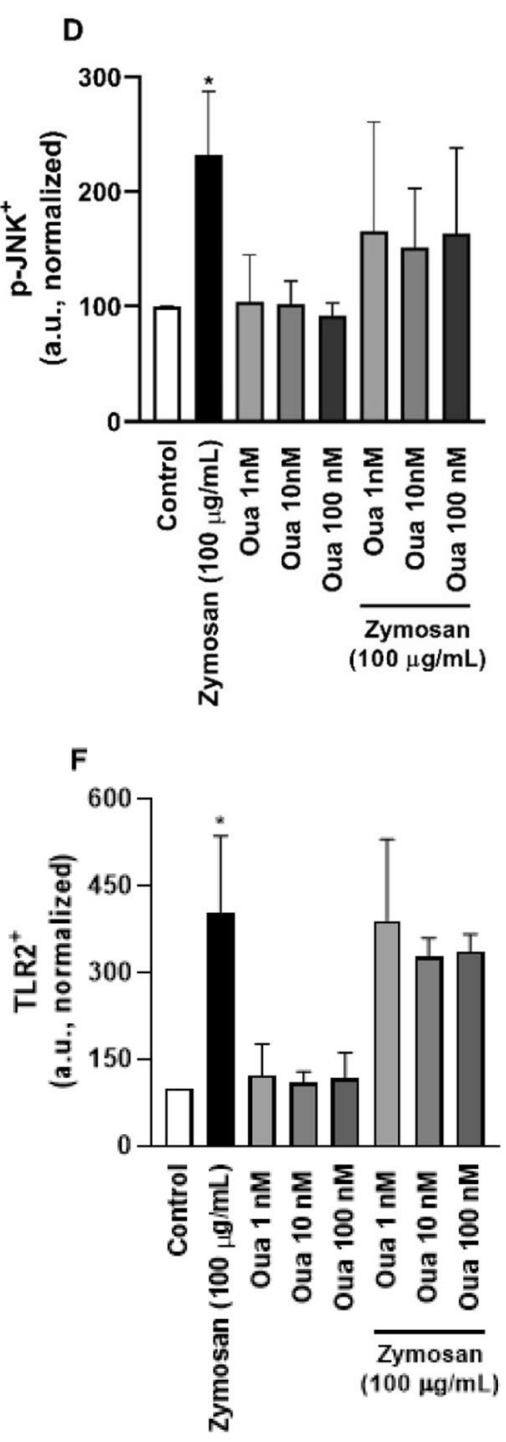
agreement with in vivo studies in which ouabain reduced neutrophil migration induced by zymosan (Leite et al. 2015). Ouabain also impairs the migration of other immune system cells, such as lymphocytes and eosinophils (Galvão et al. 2017), and different tumor cell lines (Pongrakhananon et al. 2013; Shih et al. 2017).

Since ouabain induces cell signaling pathways through NKA interaction (Cui and Xie 2017), we decide to evaluate if ouabain could interfere in intracellular signaling related to neutrophil recruitment (Mócsai et al. 2015). We previously observed a pronounced ouabain inhibitory effect in inflammatory parameters induced by zymosan in vivo (e.g., reduction of paw edema, permeability vascular, cytokine production, and cell migration). Thus, to assess the ouabain effect on neutrophil signaling, we use zymosan as the stimulus. Ouabain treatment did not modulate Akt activation induced by zymosan, a kinase that plays an important role in cell migration, regulating cytoskeletal organization during cell migration (Zhang et al. 2013). In contrast, Pongrakhananon and coworkers showed that suppression of the migration of lung cancer cells induced by ouabain seems to involve the reduction of Akt activation (Pongrakhananon et al. 2013). In the cancer cells study, ouabain was used in the picomolar range, which could justify, at least in part, the different results observed in neutrophils.

Additionally, it was observed that ouabain did not interfere with JNK and ERK phosphorylation. Different results were reported to ERK modulation by ouabain (RodriguesMascarenhas et al. 2009; De Sá Lima et al. 2013; Kinoshita et al. 2017), which may be related to cell type, the affinity of the NKA subunits for the ouabain and species cells, besides differences in experimental protocols.

The p38 MAPK signaling mediates neutrophils chemotaxis towards a chemoattractant gradient (Liew and Kubes 2019). We observed that ouabain reduced p38 phosphorylation in neutrophils and this effect is independent of reduced TLR2 expression. In thymocytes, it was also demonstrated that ouabain inhibits p-p38 (Rodrigues-Mascarenhas et al. 2008). Wang et al. 2018 also observed a negative regulatory effect of ouabain p38 expression in lung homogenates.

The cell sensitivity to ouabain various concentrations is variable, depending on the cell type, alpha subunit of the sodium pump, cell activation status, etc. A wide concentration range, from $\mathrm{pM}$ to $\mathrm{mM}$, has been studied in various experimental models. In some cells, ouabain in the picomolar range triggers different biological effects. The signal transduction mechanism triggered by ouabain low concentrations does not appear to alter the cell ionic concentration (Cui and Xie 2017). Thus, we can hypothesize that, in neutrophils, ouabain $100 \mathrm{nM}$ partially inhibits sodium pump and does not trigger p38 MAPK signaling directly. In agreement with other works that show ouabain biological effect in other models in low concentrations/doses (De
Rezende Corrêa et al. 2005; Salles von-Held-Ventura et al. 2016). However, an experimental approach needs to be done to answer this hypothesis.

In neutrophils, the p38 MAPK-dependent pathway can regulate surface receptor expression, including adhesion molecules (Kim and Haynes 2013). Thus, this could be related to the ouabain inhibitory effect on neutrophil chemotaxis. However, more studies are necessary to assess this hypothesis and to investigate other mechanisms. In summary, this study suggests a new mode of action of this hormone in immune cells to regulate inflammation and highlights immune-endocrine interactions.

Acknowledgements This research was also supported by Federal University of Paraíba.

Author contributions Conceptualization, LHAC-S and SR-M; methodology, LHAC-S, DCMC, and EAL; formal analysis, LHAC-S; investigation, LHAC-S, DCMC, and EAL; writing-original draft preparation, LHAC-S; writing - review and editing, LHAC-S and SR-M; supervision, SR-M. All authors have read and agreed to the published version of the manuscript.

Funding This research was funded by Coordenação de Aperfeiçoamento de Pessoal de Nível Superior" (CAPES), Grant number 2951/2014, and by a fellowship from "Conselho Nacional de Desenvolvimento Científico e Tecnológico (CNPq)" award number $154801 / 2019-4$

Data availability Not applicable.

\section{Declarations}

Conflict of interest The authors declare no conflict of interest.

\section{References}

Aydemir-Koksoy A, Abramowitz J, Allen JC (2001) Ouabain-induced signaling and vascular smooth muscle cell proliferation. J Biol Chem 276:46605-46611. https://doi.org/10.1074/jbc.M1061 78200

Bautista-Becerril B, Campi-Caballero R, Sevilla-Fuentes S et al (2021) Immunothrombosis in covid-19: implications of neutrophil extracellular traps. Biomolecules. https://doi.org/10.3390/biom110506 94

Cavalcante-Silva LHA, de LimaCarvalho ÉADCM et al (2017) Much more than a cardiotonic steroid: modulation of inflammation by Ouabain. Front Physiol 8:895. https://doi.org/10.3389/fphys.2017. 00895

Cavalcante-Silva LHA, de Lima ÉA, Carvalho DCM, Rodrigues-Mascarenhas S (2020) Ouabain reduces the expression of the adhesion molecule CD18 in neutrophils. Inflammopharmacology 28:787793. https://doi.org/10.1007/s10787-019-00602-8

Cavalcante-Silva LHA, Carvalho DCM, de Lima ÉA et al (2021) Neutrophils and COVID-19: the road so far. Int Immunopharmacol. https://doi.org/10.1016/j.intimp.2020.107233

Cui X, Xie Z (2017) Protein interaction and Na/K-ATPase-mediated signal transduction. Molecules. https://doi.org/10.3390/molec ules 22060990 
De Rezende CG, Araujo Dos Santos A, Leite Fontes CF, Giestal De Araujo E (2005) Ouabain induces an increase of retinal ganglion cell survival in vitro: the involvement of protein kinase $\mathrm{C}$. Brain Res 1049:89-94. https://doi.org/10.1016/j.brainres.2005.04.082

De Sá LL, Kawamoto EM, Munhoz CD et al (2013) Ouabain activates $\mathrm{NF \kappa B}$ through an NMDA signaling pathway in cultured cerebellar cells. Neuropharmacology 73:327-336. https://doi.org/10.1016/j. neuropharm.2013.06.006

de Vasconcelos DIB, Leite JA, Carneiro LT et al (2011) Anti-inflammatory and antinociceptive activity of ouabain in mice. Mediat Inflamm. https://doi.org/10.1155/2011/912925

Galvão JGFM, Cavalcante-Silva LHA, Carvalho DCM et al (2017) Ouabain attenuates ovalbumin-induced airway inflammation. Inflamm Res 66:1117-1130. https://doi.org/10.1007/ s00011-017-1092-9

Hellebrekers P, Vrisekoop N, Koenderman L (2018) Neutrophil phenotypes in health and disease. Eur J Clin Invest. https://doi.org/ 10.1111/eci.12943

Hidalgo A, Chilvers ER, Summers C, Koenderman L (2019) The neutrophil life cycle. Trends Immunol 40:584-597. https://doi.org/ 10.1016/j.it.2019.04.013

Jacob PL, Leite JA, Alves AKA et al (2013) Immunomodulatory activity of ouabain in Leishmania leishmania amazonensis-infected Swiss mice. Parasitol Res 112:1313-1321. https://doi.org/10. 1007/s00436-012-3146-9

Jones HR, Robb CT, Perretti M, Rossi AG (2016) The role of neutrophils in inflammation resolution. Semin Immunol 28:137-145. https://doi.org/10.1016/j.smim.2016.03.007

Juss JK, House D, Amour A et al (2016) Acute respiratory distress syndrome neutrophils have a distinct phenotype and are resistant to phosphoinositide 3-kinase inhibition. Am J Respir Crit Care Med 194:961-973. https://doi.org/10.1164/rccm.201509-1818OC

Kim D, Haynes CL (2013) The role of p38 MAPK in neutrophil functions: single cell chemotaxis and surface marker expression. Analyst 138:6826-6833. https://doi.org/10.1039/c3an01076g

Kinoshita PF, Yshii LM, Orellana AMM et al (2017) Alpha $2 \mathrm{Na}+$, $\mathrm{K}+$-ATPase silencing induces loss of inflammatory response and ouabain protection in glial cells. Sci Rep 7:4894. https://doi.org/ 10.1038/s41598-017-05075-9

Kolaczkowska E, Kubes P (2013) Neutrophil recruitment and function in health and inflammation. Nat Rev Immunol 13:159-175. https://doi.org/10.1038/nri3399

Leite JA, Alves AKDA, Galvão JGM et al (2015) Ouabain modulates zymosan-induced peritonitis in mice. Mediat Inflamm. https://doi. org/10.1155/2015/265798

Leliefeld PHC, Wessels CM, Leenen LPH et al (2016) The role of neutrophils in immune dysfunction during severe inflammation. Crit Care. https://doi.org/10.1186/s13054-016-1250-4

Liew PX, Kubes P (2019) The neutrophil's role during health and disease. Physiol Rev 99:1223-1248. https://doi.org/10.1152/physr ev.00012.2018

Lima TFA, Rocha JDB, Guimarães-Costa AB et al (2014) Warifteine, an alkaloid purified from cissampelos sympodialis, inhibits neutrophil migration in vitro and in vivo. J Immunol Res. https://doi. org/10.1155/2014/752923
Minns D, Smith KJ, Findlay EG (2019) Orchestration of adaptive T cell responses by neutrophil granule contents. Mediat Inflamm. https://doi.org/10.1155/2019/8968943

Mishalian I, Granot Z, Fridlender ZG (2017) The diversity of circulating neutrophils in cancer. Immunobiology 222:82-88. https://doi. org/10.1016/j.imbio.2016.02.001

Mocsai A, Zhang H, Jakus Z et al (2003) G-protein-coupled receptor signaling in Syk-deficient neutrophils and mast cells. Blood 101:4155-4163. https://doi.org/10.1182/blood-2002-07-2346

Mócsai A, Walzog B, Lowell CA (2015) Intracellular signalling during neutrophil recruitment. Cardiovasc Res 107:373-385. https://doi. org/10.1093/cvr/cvv159

Ocana A, Nieto-Jiménez C, Pandiella A, Templeton AJ (2017) Neutrophils in cancer: prognostic role and therapeutic strategies. Mol Cancer 16:137. https://doi.org/10.1186/s12943-017-0707-7

Parackova Z, Bloomfield M, Klocperk A, Sediva A (2021) Neutrophils mediate Th17 promotion in COVID-19 patients. J Leukoc Biol 109:73-76. https://doi.org/10.1002/JLB.4COVCRA0820-481RRR

Phillipson M, Kubes P (2019) The healing power of neutrophils. Trends Immunol 40:635-647. https://doi.org/10.1016/j.it.2019.05.001

Pongrakhananon V, Chunhacha P, Chanvorachote P (2013) Ouabain suppresses the migratory behavior of lung cancer cells. PLoS ONE. https://doi.org/10.1371/journal.pone.0068623

Ray E, Samanta AK (1997) Receptor-mediated endocytosis of Il-8: a fluorescent microscopic evidence ligand-induced biological response in human neutrophils. Cytokine 9:587-596

Rodrigues-Mascarenhas S, Bloise FF, Moscat J, Rumjanek VM (2008) Ouabain inhibits p38 activation in thymocytes. Cell Biol Int 32:1323-1328. https://doi.org/10.1016/j.cellbi.2008.07.012

Rodrigues-Mascarenhas S, De Oliveira ADS, Amoedo ND et al (2009) Modulation of the immune system by Ouabain. Ann N Y Acad Sci 1153:153-163. https://doi.org/10.1111/j.1749-6632.2008.03969.x

Salles von-Held-Ventura J, Mázala-de-Oliveira T, Cândida da Rocha Oliveira A et al (2016) The trophic effect of ouabain on retinal ganglion cells is mediated by IL- $1 \beta$ and TNF- $\alpha$. Biochem Biophys Res Commun. https://doi.org/10.1016/j.bbrc.2016.07.043

Shih YL, Au MK, Liu KL et al (2017) Ouabain impairs cell migration, and invasion and alters gene expression of human osteosarcoma U-2 OS cells. Environ Toxicol 32:2400-2413. https://doi.org/10. 1002/tox.22453

Summers C, Rankin SM, Condliffe AM et al (2010) Neutrophil kinetics in health and disease. Trends Immunol 31:318-324. https://doi. org/10.1016/j.it.2010.05.006

Wang C, Meng Y, Wang Y et al (2018) Ouabain protects mice against lipopolysaccharide-induced acute lung injury. Med Sci Monit 24:4455-4464. https://doi.org/10.12659/MSM.908627

Zhang Y, Wang X, Yang H et al (2013) Kinase AKT controls innate immune cell development and function. Immunology 140:143152. https://doi.org/10.1111/imm.12123

Publisher's Note Springer Nature remains neutral with regard to jurisdictional claims in published maps and institutional affiliations. 